\section{SOME PROPERTIES OF PHOSPHORIC ACID STABILISED LATERIZED ADOBE BRICKS}

\author{
Abdulhalim Oshioke Mohammed, Adekemi Loretta Ayodele*, \\ Adeyemi Babayemi Fajobi, Akindehinde Ayotunde Akindahunsi, \\ Aderopo Musiliu Olajumoke
}

Department of Civil Engineering, Faculty of Technology, Obafemi Awolowo University, Ile-Ife, Nigeria
Article history Received

15 July 2020

Received in revised form

21 August 2020

Accepted

28 August 2020

Published online

30 November 2020

*Corresponding author layodele@oauife.edu.ng

\begin{abstract}
The changes in the compressive strength of laterized bricks produced from stabilised residual tropical laterite (RTL) are reported in this paper. The RTL was stabilised with different percentages $(2,4,6$ and $8 \%$ ) by weight of dry soil of $1 \mathrm{M}$ phosphoric acid (PA). Some geotechnical properties and elemental oxide composition of the RTL were determined. Adobe bricks were produced from the PA stabilised, $5 \%$ cement stabilised and unstabilised RTL. Adobe bricks produced from $5 \%$ cement stabilised RTL served as the control. The bricks were cured under ambient air condition for $7,14,21$ and 28 days. The $\mathrm{pH}$, dry density, moisture content and compressive strength $\left(f_{c}\right)$ of the bricks were determined at the end of each curing period. The influence of PA was evaluated using the changes in the $f_{c}$ of the adobe bricks. The effectiveness of PA was also evaluated using a standard minimum requirement. Statistical analysis of the results was done using Analysis of variance. There was about 90 and $200 \%$ increase in $f_{c}$ of PA and cement stabilised Adobe bricks, respectively. The $\mathrm{f}_{c}$ of $6 \%$ PA stabilised and cement stabilised adobe bricks met the minimum requirement. It is concluded that PA has great potential for stabilising Adobe bricks for building.
\end{abstract}

Keywords: Soil stabilization, laterized adobe bricks, analysis of variance, compressive strength, phosphoric acid

\subsection{INTRODUCTION}

The word "Adobe" is used generally to describe different earth materials employed in building construction and the method in which they are used. It is an Arabic and Berber word brought by the Spaniards into America where it was adopted into English [1]. Adobe bricks are one of the most recognised and broadly utilised structural materials. Utilisation of these sun-dried bricks goes back to 8000 B.C [2]. Soil for adobe brick production contains three principal components which are sand, silt and clay [3]. The clay component acts as a binder while the sand component acts as an inert filler and helps to limit the formation of cracks in the bricks as a result of shrinkage [1].

Adobe bricks can be easily produced by mixing earth material and water together, and putting the resulting mix in moulds. Then the mixture in the mould is left to air dry without exposure to direct the sunlight [4]. Construction of buildings with adobe bricks offers thermal comfort in hot weather conditions (which is typical of tropical climate) and have low levels of sound transmission through walls [5]. They store heat and reduce the rate at which heat is transferred into the building [6]. Adobe bricks are also durable, non-toxic, firepro of and economic [5].

Despite the fact that the usage of adobe bricks has some advantages, they fall short of some requirements. They have reasonably low compressive strength, low tensile strength, low scratch resistance and low resistance to water absorption. In order to remedy these deficiencies, additives can be adde $d$ to the soil from which the adobe bricks are produced. These additives are known as stabilisers. The two main chemical additives which have been used over the years for soil stabilisation are cement and lime [7] and are sometimes referred to as traditional stabilisers. The cost of these stabilizers, however, has increased due to the cost of energy since 1970 [8]. Production of cement (which is most widely successfully used) also requires massive energy and releases 
pollutants into the environment [9], thus it is important to source for alternative stabilisers which are environmentally friendly.

In the tropics, there is abundance of residual laterites and lateritic soils which are used for adobe brick production. It has been shown that the properties of some of these tropical laterites need to be improved [10]. In the specific case of stabilised laterite soil for adobe brick production, some studie s have used cement and natural rubber latex [6], sawdust and egg shell ash [11], coconut shell ash [12]. The laterite soils collected from different locations were stabilised with different percentages of the additives. There was improvement in the compressive strengths of the adobe bricks produced. Most of the additives used in the previous researches are either silica and/or calcium based.

It has been shown that laterite and lateritic soils being acid soils and rich in iron and aluminium, can be successfully stabilised with phosphoric acid $[13,14,15,16,17,18]$. This is due to the fact that the stabilisation process occurs as a result of acid attack on clay minerals in soil, thereby dissolving their aluminium and iron content. The aluminium content is precipitated as hydrated aluminium phosphate [14]. The results from the studies of chemically stabilised soils have show $n$ that the efficiency of the treatment relies mainly on the soil's natural environment [15]. Phosphoric acid cannot be used as a standalone additive for stabilising soils that have high silt content and low clay content. This is because the acid will attack the silica (silt) at a slow rate at room temperature [14]. The reactions of phosphates with the soil are given in the equations (1) and (2).

$\mathrm{Al}^{3+}+2 \mathrm{OH}^{-}+\mathrm{H}_{2}+\mathrm{PO}_{4}^{-}+x \mathrm{H}_{2} \mathrm{O} \rightarrow \mathrm{Al}(\mathrm{OH})_{2} \mathrm{H}_{2} \mathrm{PO}_{4} \cdot \mathrm{xH}_{2} \mathrm{O}$

$\mathrm{Fe} 2 \mathrm{O} 3+\mathrm{H}_{2} \mathrm{PO}_{4}^{-}+\mathrm{xH}_{2} \mathrm{O} \rightarrow \mathrm{Fe}(\mathrm{OH})_{2} \mathrm{H}_{2} \mathrm{PO}_{4} \cdot \mathrm{xH}_{2} \mathrm{O}$

The iron and aluminium oxides formed are hard and insoluble [19]. Phosphoric acid is non-toxic in nature and it is easier and cheaper to transport than the traditional bulky stabilisers such as lime and cement [16].

Despite the fact that some researches have shown that phosphoric acid can be used to stabilise laterite soils, it's use in stabilising laterite soils for adobe bricks production is not existing or scanty in the literature. Thus, in this paper, the use of phosphoric acid in stabilising a residual tropical laterite (RTL) for adobe production is explored.

\subsection{MATERIALS AND METHODOLOGY}

Disturbed residual tropical laterite (RTL) soil sample was collected from an existing borrow pit with coordinates $N 7^{\circ} 29^{\prime} 53.18486^{\prime \prime} \mathrm{E}$ and $4^{\circ} 26^{\prime} 56.48961^{\prime \prime} \mathrm{E}$ in Southwestern Nigeria. The index properties such as specific gravity,
Atterberg's limit (Liquid Limit LL, Plastic Limit, PL, and Plastic Index, PI), Particle Size Distribution (PSD) of the RTL were determined according to ASTM D 854, ASTM D 4318 and ASTM D 422, respectively. The moisture-density relationship (Optimum Moisture Content, OMC and Maximum Dry Density, MDD) of the RTL were also determined according to ASTM D 698. The $\mathrm{pH}$ of the RTL was determined using a pocket $\mathrm{pH}$ meter. The elemental oxides in the RTL were determined using Particle Induced X-ray Emission (PIXE). Varying percentages ( 0 , 2, 4, 6 and $8 \%$ ) of $1 \mathrm{M}$ phosphoric acid, $\mathrm{H}_{3} \mathrm{PO}_{4}$ (PA) were mixed with the RTL for stabilisation purpose. The design mix is presented in Table 1.

Adobe bricks of dimensions $300 \mathrm{~mm} \times 150 \mathrm{~mm} \times 75 \mathrm{~mm}$ with two central circular hole of $85 \mathrm{~mm}$ diameter and edge thickness of $32.5 \mathrm{~mm}$ as presented in Figure 1 were produced after mixing the stabilised laterite thoroughly with mechan ic al pot mixer and pressed with hydraulic press machine.

Control adobe bricks were also produced from 5\% cement stabilised RTL. $5 \%$ of cement is the recommended maximum percentage for laterite by the Nigerian Building and Road research Institute (NIBRRI) [20]. The bricks were cure d at $7,14,21$ and 28 days under ambient air condition. The $\mathrm{pH}$, moisture content, dry density and compressive strength $\left(f_{c}\right)$ of the bricks were determined at the end of each curing period. Soil samples collected after crushing the bricks were used to determine the $\mathrm{pH}$ and moisture content. The $\mathrm{pH}$ was determined using a pocket $\mathrm{pH}$ meter and moisture content was determined using the oven method (ASTM D 2216). The dry density $\left(\rho_{d}\right)$ of the brick was determined by using $\rho_{d}=$ $M / V(1+w)$. Where $M$ is the mass of the brick at the end of curing period, $V$ is the volume of the brick and $w$ is the moisture content. The mass of the brick was determined before crushing with a weighing balance. The $f_{\mathrm{c}}$ of each adobe bricks was determined in accordance with ASTM C 67. The bricks were tested for compressive strength by placing them in such a manner that the load-bearing surface of the brick faced the upper plate in the loading compartment of the machine. The $n$ the upper plate was lowered until it touched the brick surface before switching on the machine. The load at which each brick failed was recorded and the compressive strength was determined by $f_{\mathrm{c}}=P / A$, where, $\mathrm{P}$ is the load at failure in $\mathrm{N} / \mathrm{m} \mathrm{m}^{2}$ and $A$ is the net surface area of the adobe bricks in $\mathrm{mm}^{2}$. Three bricks were tested for each percent of stabilization and curing period and the average value determined.

In order to evaluate the effectiveness of PA in stabilizing the RTL for adobe brick production, the $f_{\mathrm{c}}$ of adobe bricks produced from PA stabilised RTL were compared with the minimum standard value of $1.65 \mathrm{~N} / \mathrm{mm}^{2}$ recommended by NIBRRI [20]. One-way analysis of variance was also used to determine the statistical significance of the results. 
Table 1 Design Mix

\begin{tabular}{|c|c|}
\hline Stabilizer & Curing period \\
\hline \multirow[t]{4}{*}{ None } & 7 \\
\hline & 14 \\
\hline & 21 \\
\hline & 28 \\
\hline \multirow[t]{4}{*}{$2 \% \mathrm{PA}$} & 7 \\
\hline & 14 \\
\hline & 21 \\
\hline & 28 \\
\hline \multirow[t]{4}{*}{$4 \%$ PA } & 7 \\
\hline & 14 \\
\hline & 21 \\
\hline & 28 \\
\hline \multirow[t]{4}{*}{$6 \% \mathrm{PA}$} & 7 \\
\hline & 14 \\
\hline & 21 \\
\hline & 28 \\
\hline \multirow[t]{4}{*}{$8 \%$ PA } & 7 \\
\hline & 14 \\
\hline & 21 \\
\hline & 28 \\
\hline \multirow[t]{4}{*}{$5 \%$ Portland cement } & 7 \\
\hline & 14 \\
\hline & 21 \\
\hline & 28 \\
\hline
\end{tabular}

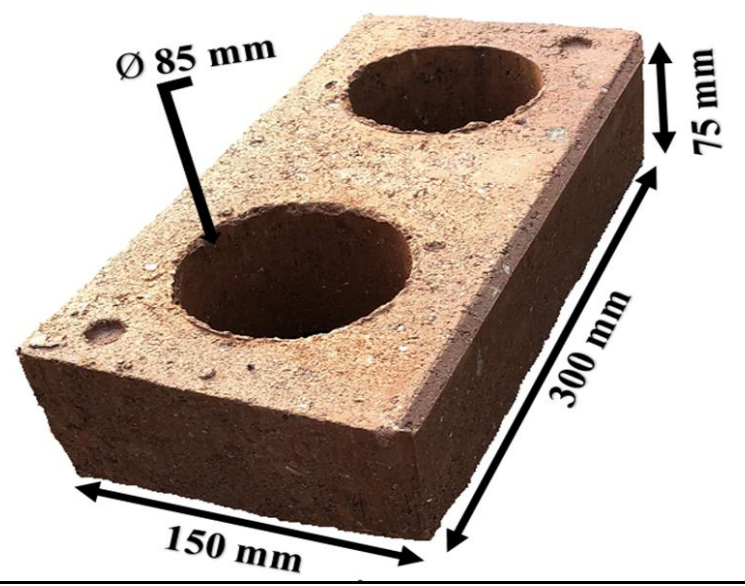

Figure 1 Moulded adobe bricks with dimensions

\subsection{RESULTS AND DISCUSSION}

\subsection{Preliminary Analysis}

The index and compaction properties of the RTL are prese nted in Table 2. The natural moisture content is very high because the RTL was collected from a borrow pit during the raining season. According to [21] high value of natural moisture content implies that the laterite sample is a silty or clayey soil.

fThe particle size distribution results show that the clay and silt fraction (fines content) of the soil is more than $50 \%$, thus the soil is fine grained according to Unified Soil Classification System (USCS). This result indicates that the RTL can be effectively stabilised with phosphoric acid (PA) based on [14] which showed that PA is effective for the stabilisation of fine-grained soils. The clayey nature of the RTL indicates that the soil has the ability to retain water. The specific gravity of the RTL falls between the range of 2.5 to 2.75 which shows that the RTL is a good lateritic material [22]. According to AASHTO soil classification, specific gravity between 2.35 and 2.7 confirms that the soil has a high content of clay or silt. The RTL is acidic based on its $\mathrm{pH}$ (Table 2). Acidic $\mathrm{pH}$ is typical of RTL $[15,23]$.

The Plasticity index (PI) of the RTL is greater than $11 \%$, thus the soil can be considered as clayey soil based on [24] which classified soils with PI greater than or equal to $11 \%$ as clayey 
soils. The liquid limit (LL) of the RTL shows that the soil is classified as low plasticity soil. Combining the particle size distribution and Atterberg's limits results, the RTL can be classified as low plasticity clay $(\mathrm{CL})$ according to the unified soil classification system.

\subsection{Chemical Analysis}

Comprehensive elemental oxide composition of the RTL is presented in Table 3. According to [14], when the ratio of the silica oxide $\left(\mathrm{SiO}_{2}\right)$ to sesquioxide $\left(\mathrm{MnO}, \mathrm{TiO}_{2}, \mathrm{Fe}_{2} \mathrm{O}_{3}, \mathrm{Al}_{2} \mathrm{O}_{3}\right)$ in a soil is less than 1.33, the soil should be classified as a laterite. The RTL is therefore classified as laterite because the ratio of the silica oxide to sesquioxides is less than 1.33.

\subsection{Moisture Contents of the Adobe Bricks}

The moisture contents were determined to know the amount of moisture present in the bricks at the end of each curing period. According to [24], moisture content has a significant effect on the compressive strength of adobe bricks. The variation of moisture content of the adobe bricks with curing periods is presented in Figure 2. The moisture content at zero day represents the water content of moulding the brick. The results show that the moisture content of the bricks decreased with increasing curing period for all treated and untreated bricks. This is as a result of the gradual drying out of moisture from the adobe bricks through the passage of time as they were cured under ambient condition in the laboratory. Statistical analysis using Analysis of variance (ANOVA) showed that both percentage of PA $(p=0.0015)$ and curing period $(p=$ $3.73 \times 10-6)$ have significant effects on the brick's moisture contents with $p<0.05$.

\subsection{Dry Density of Adobe Bricks}

The dry densities of the adobe bricks were determined at the end of each curing period. The variation of the brick's dry densities with curing periods is presented in Figure 3 . The results show that the dry densities of the bricks decreased with curing periods. This might be as a result of the gradual loss of moisture from the bricks over the curing periods.

Table 2 Index and compaction properties of the untreated RTL

\begin{tabular}{|c|c|}
\hline Property & Value \\
\hline Natural moisture content (\%) & 25.61 \\
\hline Moisture content before moulding (\%) & 13.24 \\
\hline Specific Gravity (Gs) & 2.50 \\
\hline Percent of particles finer than $75 \mu \mathrm{m}$ & 55.40 \\
\hline Liquid Limit (LL) \% & 47.16 \\
\hline Plastic Limit (PL) \% & 25.04 \\
\hline Plasticity Index (PI) \% & 22.12 \\
\hline Maximum Dry Density (MDD) g/cm ${ }^{3}$ & 1.61 \\
\hline Optimum Moisture Content (OMC) \% & 24.80 \\
\hline pH of the laterite in distilled water & 6.44 \\
\hline
\end{tabular}

Table 3 Elemental Oxides of the RTL

\begin{tabular}{|c|c|c|c|}
\hline Element & Oxide & Element Concentration (ppm) & Oxide Concentration (ppm) \\
\hline $\mathrm{Na}$ & $\mathrm{Na}_{2} \mathrm{O}$ & 983 & 1325 \\
\hline $\mathrm{Mg}$ & $\mathrm{MgO}$ & 3900 & 6466 \\
\hline Al & $\mathrm{Al}_{2} \mathrm{O}_{3}$ & 166844 & 315248 \\
\hline Si & $\mathrm{SiO}_{2}$ & 233378 & 499270 \\
\hline$P$ & $\mathrm{P}_{2} \mathrm{O}_{5}$ & 366 & 838 \\
\hline S & $\mathrm{SO}_{3}$ & 131 & 326 \\
\hline $\mathrm{Cl}$ & $\mathrm{Cl}$ & 351 & 351 \\
\hline K & $\mathrm{K}_{2} \mathrm{O}$ & 5591 & 6735 \\
\hline $\mathrm{Ca}$ & $\mathrm{CaO}$ & 2630 & 3680 \\
\hline Sc & $\mathrm{Sc}_{2} \mathrm{O}_{3}$ & 79 & 121 \\
\hline $\mathrm{Ti}$ & $\mathrm{TiO}_{2}$ & 7786 & 12987 \\
\hline $\mathrm{Cr}$ & $\mathrm{Cr}_{2} \mathrm{O}_{3}$ & 937 & 1369 \\
\hline $\mathrm{Mn}$ & $\mathrm{MnO}$ & 906 & 1170 \\
\hline $\mathrm{Fe}$ & $\mathrm{Fe}_{2} \mathrm{O}_{3}$ & 110628 & 157175 \\
\hline
\end{tabular}




\begin{tabular}{llcc}
$\mathrm{Cu}$ & $\mathrm{Cu}_{2} \mathrm{O}$ & 24 & 27 \\
$\mathrm{Zn}$ & $\mathrm{ZnO}$ & 287 & 357 \\
$\mathrm{Ga}$ & $\mathrm{Ga}_{2} \mathrm{O}_{3}$ & 211 & 283 \\
$\mathrm{Rb}$ & $\mathrm{Rb}_{2} \mathrm{O}$ & 83 & 91 \\
$\mathrm{Cd}$ & $\mathrm{CdO}$ & 791 & 904 \\
\hline
\end{tabular}

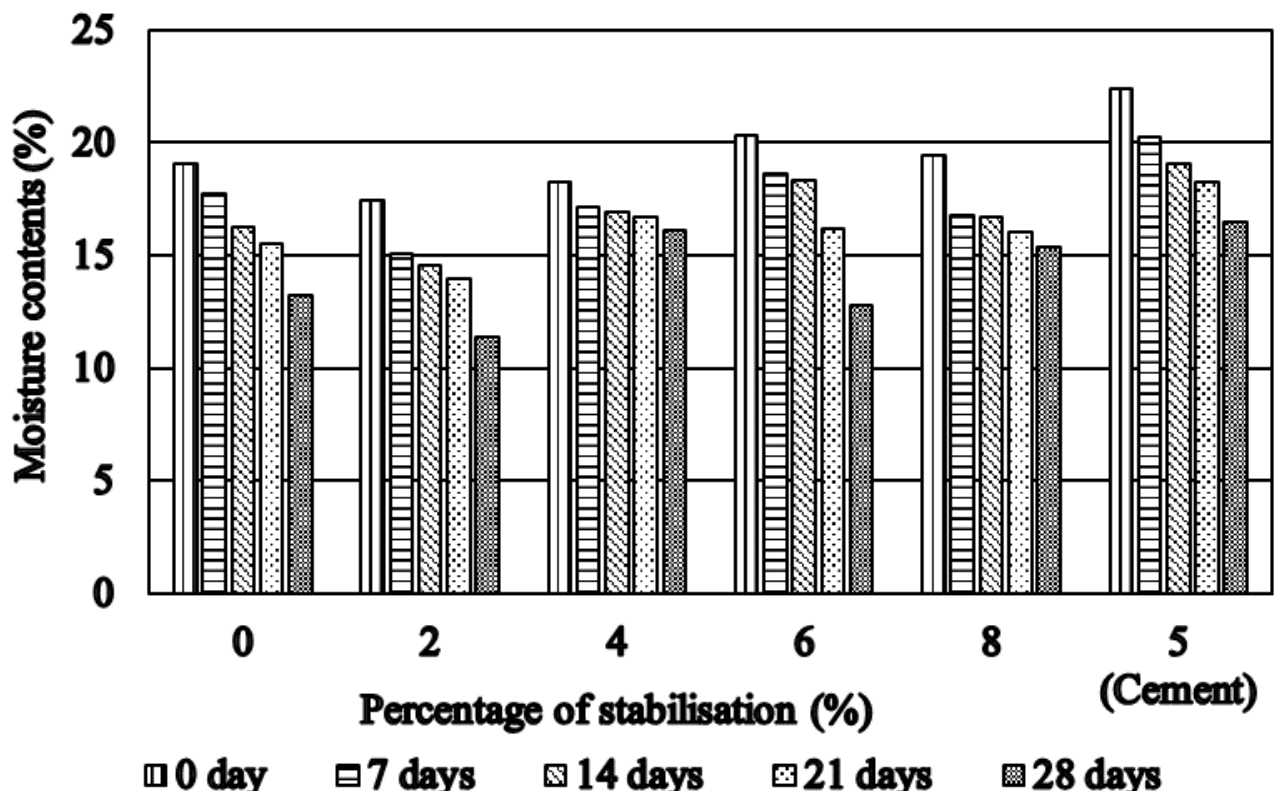

Figure 2 Variation of moisture content of the adobe bricks with curing periods

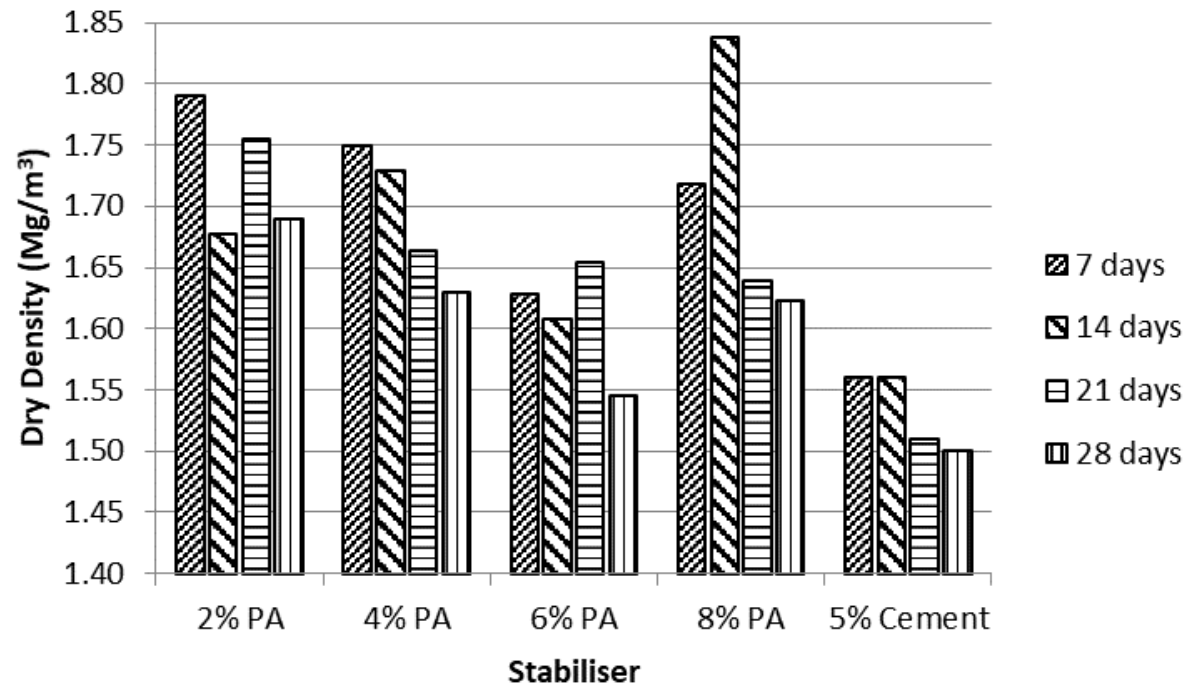

Figure $\mathbf{3}$ Variation of dry density of the adobe bricks with curing periods

\subsection{The pH of Adobe Bricks}

The Langmuir equation is applicable to homogeneous adsorption where the adsorption of each adsorbate molecule on to the surface has equal adsorption activation energy. When
$\mathrm{Ce} / \mathrm{qe}$ was plotted against $\mathrm{Ce}$, a straight line with slope of 1/Qm was obtained. The values of $\mathrm{Qm}$ and $\mathrm{KL}$ were determined from the Langmuir plots and are presented in Table 1 . The adsorption data of atrazine on both oil palm shell-based adsorbent and activated carbon were not fitted well into 
Langmuir isotherm as the correlation coefficients, R2 obtain ed were relatively low. Furthermore, the negative values of Langmuir constants for oil palm shell-based adsorbent indicated the inadequacy of Langmuir isotherm to describe the The $\mathrm{pH}$ of the treated RTL soil is presented in Figure 4. It was important to determine the $\mathrm{pH}$ of the treated soil in order to ascertain the possibility of formation of cementitious compounds which can result in strength gain within the brick. According to [17], $\mathrm{pH}$ plays a significant role in the formation of cementitious compounds during the stabilisation of laterite. This is because the phosphates from phosphoric acid will react with the iron and aluminium oxides present in laterite in a highly acidic environment to produce the cementitious compounds. Calcium ions form cement will only react in a highly alkaline environment to produce the cementitious compounds [17].

The results show that the RTL became more acidic with the addition of PA and became basic with the addition of cement. The low $\mathrm{pH}$ of the PA displaced the $\mathrm{pH}$ of the untreated RTL and brought about low pH of the PA-RTL mixture in the early stage. The high $\mathrm{pH}$ of cement also displaced the $\mathrm{pH}$ of the untreated RTL and brought about a high $\mathrm{pH}$ of the cement-RTL mixture in the early stage of curing. The $\mathrm{pH}$ of PA treated RTL increased with increasing curing age while the $\mathrm{pH}$ of cement treated RTL reduced as the curing age increased. This can be attributed to the hydration of cement as the cement reacted with the water in the bricks to bind the soil particles together. Statistical analysis shows that both curing period and concentrations of PA have significant effect on the $\mathrm{pH}$ of the adobe bricks with $\mathrm{p}=0.007$ and 0.02 , respectively.

According to [25], aluminium is most active in precipitating phosphates at a pH of 5.0 to 6.5 , while iron is especially active below 4.0. It can thus be said that since the $\mathrm{pH}$ of the PA stabilised bricks ranged between 5 and 6.5, aluminium phosphate precipitate is most likely to be formed within the brick and not iron phosphate precipitates. It has al so been shown (Table 2 ) that the RTL is rich in aluminium oxides.

\subsection{Compressive Strength of Adobe Bricks}

The variation of the compressive strength $(\mathrm{fc}$ ) of the adobe bricks with the amount of stabiliser and curing periods is presented in Figure 5. The results show that the fc of the adobe bricks generally increased with increasing curing age for each percentage of PA and for $5 \%$ cement. The fc, however, reduced ( $7 \%$ reduction) slightly at 28 days of curing for $2 \%$ PA stabili ised adobe brick. Comparing the fc of stabilised bricks at each curing day with fc of $0 \%$ PA stabilised bricks as references, PA has a positive effect on the $\mathrm{fc}$ of the adobe bricks with the highest increase of about $164 \%$ for $2 \%$ PA stabilised at 7 days of curing. At both 21 and 28 days of curing, the fc increased with increasing percentage of PA up to $6 \%$ and reduced for $8 \%$ PA stabilised adobe bricks. This reduction in fc can perhaps be attributed to reduced workability of the $8 \%$ stabilised RTL. When $8 \%$ of PA was mixed with the RTL, the treated RTL formed lumps which made it difficult to work the soil until more water was added to the mix. The addition of water resulted in slightly porous bricks. The formation of lumps and reduced workability was also observed when higher concentrations of PA were attempted during the trial stage.

The increase in $\mathrm{fc}$ over the curing periods is in agreeme $\mathrm{nt}$ with the works of $[26,27]$. The increase in fc with curing periods could also be as a result of the curing periods which provided more time for considerable amount of hydration to take place. It was shown by [13] that after stabilisation with phosphoric acid, curing is vital before testing to allow for a considerable amount of hydration to take place. The increase in fc over the curing periods can also be attributed to the gradual loss of moisture from the bricks over the curing periods The increase in strength as a result of the loss of moisture content is in agreement with the work of [26] which showed that the fc of adobe bricks increases with decrease in moisture content.

Statistical analysis of the results show that both percentage of PA and curing age have significant effect on the fc of stabilised bricks with $p=0.0122$ and $5.81 \times 10^{-5}$.

The $f_{c}$ of cement stabilised bricks was, however, much higher than that of PA stabilised bricks as presented in Fig 5 . This implies that cement stabilisation of RTL for adobe bricks is more efficient. The results also show that only the fc of $6 \%$ stabilised brick met the minimum requirement by NIBBRI [20]. Comparism of $f_{c}$ result with that of dry density show that dry density does not have any effect on the fc of adobe bricks. Even though cement stabilised bricks have the lowest dry densities, they also have the highest $\mathrm{f}_{\mathrm{c}}$. 


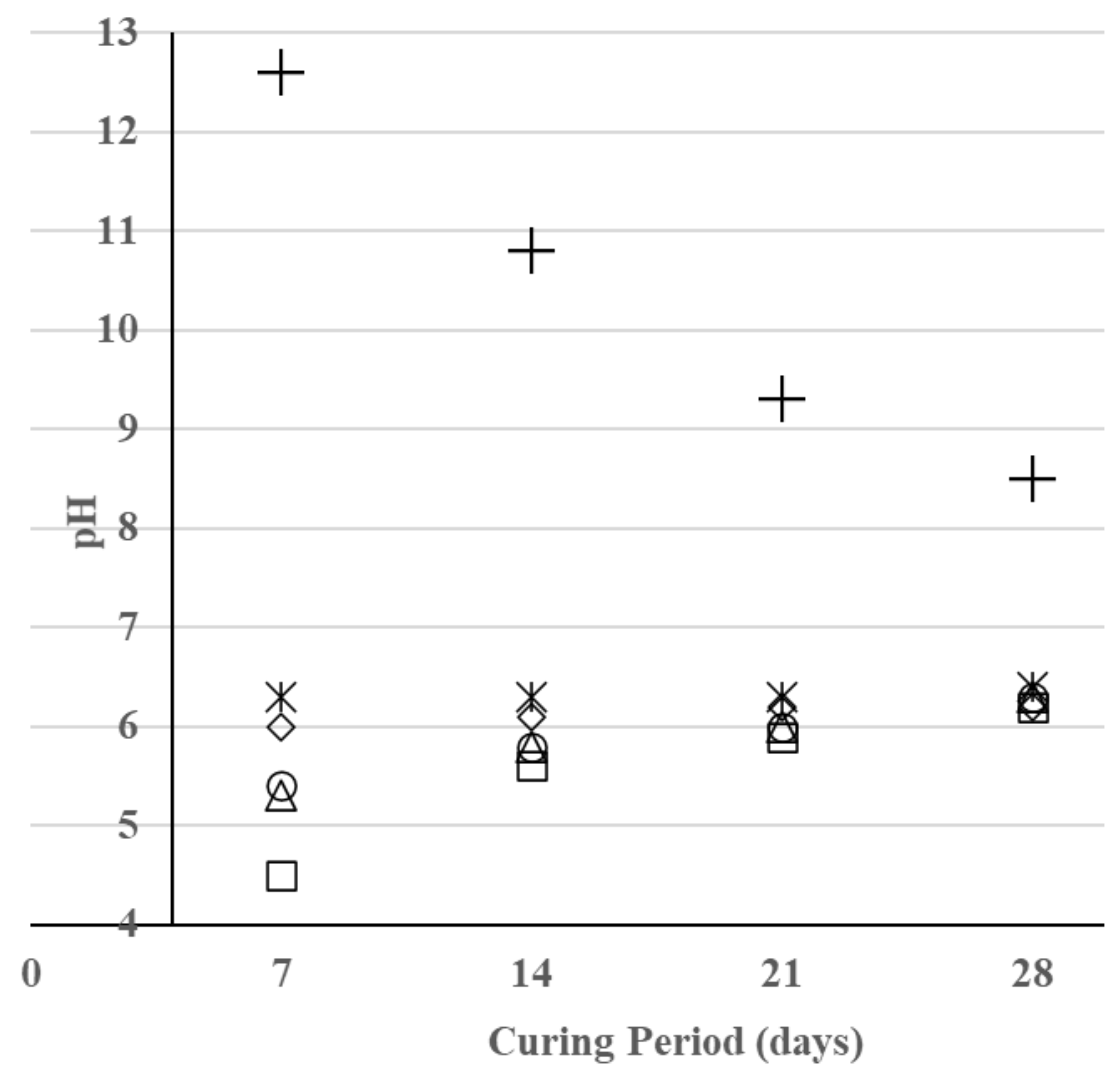

$* 0 \% \quad \diamond 2 \% \quad \bigcirc 4 \% \quad \Delta 6 \% \quad \square 8 \% \quad+5 \%$ Cement

Figure 4 Variation of $\mathrm{pH}$ of treated adobe bricks with curing periods

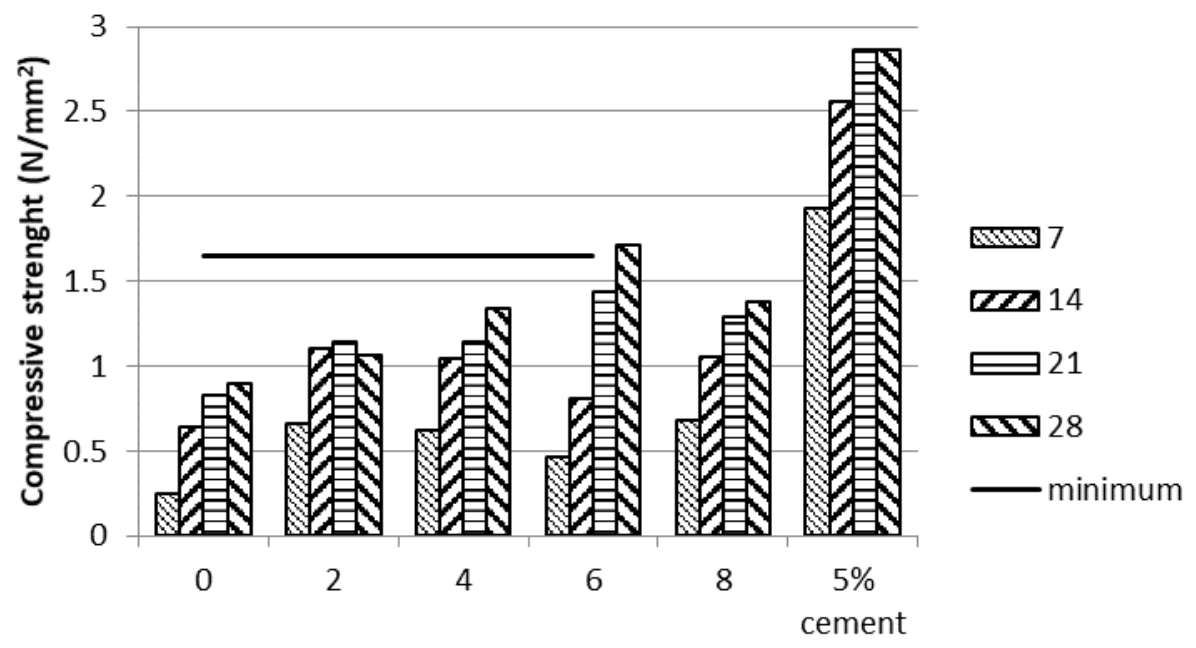

$\%$ Stabiliser

Figure 5 Variation of the compressive strength of the adobe bricks with curing periods.

\subsection{CONCLUSIONS}

The suitability of phosphoric acid in stabilising a residual tropical lateritic soil for adobe brick production has been investigated in this study. The investigation was done using laboratory studies and statistical analysis (using one-way analysis of variance) of the results were carried out. The role of $\mathrm{pH}$ for effective stabilisation was also explored. It can be concluded from the study that the stabilisation of the RTL with phosphoric acid for adobe brick production was found effective in improving the compressive strength although the improvement was smaller than that obtained in cement stabilised brick. Considering, however, the negative 
environmental impact the production of cement has, it is worth finding an alternative to the use of cement as a construction material. Since phosphoric acid is a mineral acid and has no detrimental impact on the environment, it is recommended that further studies using higher molarity of phosphoric acid should be explored. Ways of overcoming poor workability associated with higher molarity will also be investigated in further studies.

\section{Acknowledgements}

The authors wish to thank Engr. Kayode Adeloye, the Director of Sammy Lammy block Industry from where the lateritic bricks were produced.

\section{References}

[1] Sahu MK, and Singh L. 2017 Critical Review on Types of Bricks Type 4 Adobe Bricks. International Journal of Mechanical and Production Engineering. 11:116-119.

[2] Houben H, and Guillaud H. 1994. Earth construction; International comprehensive guide., 1st editio. London UK: ITDG Publishing.

[3] Smith EW, Puebio SJ. 1981. Adobe brick production in New Mexico. New mexico bureau of mines and mineral resources. 3(2): 17-24.

[4] Bahobail M A. 2012. The Mud Additives and their Effect on Thermal Conductivity of Adobe Bricks. Journal of Engineering Sciences. 40(1) 21-34. Corpus ID: 106398666

[5] Benghida D. 2015. Adobe Bricks: The Best Eco-Friendly Building Material. Advanced Materials Research. 1105 (May 2015): 386-390. https://doi.org/10.4028/www.scientific.net/AMR.1105.386

[6] Begum R, Habib A, Begum HA (2014). Adobe Bricks Stabilized With Cement and Natural Rubber Latex. International Journal of Emerging Science and Engineering. 2(4): 36-38.

[7] Oyediran IA, Ayeni OO 2020. Comparative effect of microbial induced calcite precipitate, cement and rice husk ash on the geotechnical properties of soils. SN Applied Sciences https://doi.org/10.1007/s42452-020-2956-0. 2(1157).

[8] Neville AM (2011). Properties of Concrete (Fifth Edit). Edinburgh Gate Harlow Essex CM20 2JE England: Pearson Education Limited.

[9] Chen C, Habert G, Bouzidi Y, Jullien A. 2010. Environmental inpact of cement production: detail of the different processe and cement plant variability evaluation. Journal Of Cleaner Production. 18(5): 478-485. https://doi.org/10.1016/j.jclepro.2009.12.014

[10] Olofinyo OO, Olabode OF, Fatoyinbo IO. 2019. Engineering properties of residual soils in part of Southwesten Nigeria: Implication for road foundation. SN Applied Sciences https://doi.org/10.1007/s42452 019-0515-3 . 1(507).
[11] Ayodele AL, Oketope OM, Olatunde OS. 2019. Effects of Sawdust Ash and Eggshell Ash on Selected Engineering Properties of Lateralized Bricks for Low Cost Housing. Nigerian Journal of Technology. 38(2) 278-282. DOI: $10.4314 /$ njt.v38i2.1

[12] Olajumoke AM, Olonade KA, Obaye UJ, Ishola OO. 2011. A Study of Some Engineering Properties of Coconut Shells Ash Stabilised Lateritic Bricks for Affordable Housing. Proceeding Fac. Technol. Conf. Innov. Technoogies Socio-economic Transform. Dev. Countries. lle-Ife, Nigeria., 89-95.

[13] Lyons JW, McEwan GJ. 1961. Use of phosphoric acid in soil stabilization. Highway Research Board Bulletin. 282:4-14.

[14] Bell FG (1993). Engineering treatment of soils, in Engineering Treatment of Soils, First edit., The Promotion Department, E \& FN Spon, London SE1 8HN: E \& FN Spon, 259.

[15] Eisazadeh A, Kassim KA, Nur H. 2011a. Characterization of phosphoric acid- and lime-stabilized tropical lateritic clay, Environmental Earth Sciences. 63 (5): 1057-1066. https://doi.org/10.1007/s12665-010 0781-2

[16] Eisazadeh A, Kassim KA, Nur H. 2011b. Stabilization of tropical kaolin soil with phosphoric acid and lime, Natural Hazards. 61(3): 931-942. DOI: 10.1007/s11069-011-9941-2

[17] Ayodele AL, Agbede OA. 2017. Influence of Electrochemical Treatment on a Typical Laterite, Ground Improvement. 171(2): 1-9. http://doi.org/10.1680/jgrim.16.00030

[18] Ayodele A L, Pamukcu S, Shrestha A R, Agbede O A. 2018 Electrochemical Soil Stabilization and Verification, Geotech Geotechnical and Geological Engineering. 36(2): 12831293. https://doi.org/10.1007/s10706-017-0392-8

[19] Medina J, and Guida HN. 1995. Stabilization of Lateritic Soils with Phosphoric Acid. Geotech. Geotechnical and Geological Engineering. 13: 199-216. https://doi.org/10.1007/BF00422210

[20] A. A. Raheem, O. A. Bello, and O. A. Makinde, 2010. "A comparative study of cement and lime stabilized lateritic interlocking blocks," The Pacific Journal of Science and Technology, 11(2): 27-34

[21] Das BM. 2002. Soil Mechanics Laboratory Manual, $6^{\text {th }}$ Ed. California: New York Oxford University Press.

[22] Alabo EH, Pandy P (1987). Distribution of Engineering Properties of Red Soils in the Central Lower Niger Delta, Nigeria. Proceeding 9th African Regional Conference on Soil Mechanics and Foundation Engineering. Lagos, 49-55.

[23] Gidigasu MD. 1976. Laterite Soil Engineering: Pedogenesis and Engineering Principles, Elsevier Sci. Publ. Company, Amsterdam.. 150.

[24] Das B M. 2006. Principles of Geotechnical Engineering, Seventh. Cengage Learning. 98.

[25] Potash and potash institute (1998). Phosphorus mobility in perspective.https://www.nrcs.usda.gov/Internet/FSE_DOCUMENTS/ nrcs142p2 053254.pdf. Accessed on Novemebr 28, 2013.

[26] Clifton JR, Davis FL. 1979. Mechanical Properties of Adobe Washington, D.C. 20234.

[27] Salim RW, Ndambuki JM, Adedokun DA. 2014. Improving the bearing strength of sandy loam soil compressed earth block bricks using Sugercane Bagasse Ash. Sustainability. 6(6):3686-3696 